\title{
Predicting The Relationship Between The Modulus Of Rupture And Compressive Strength Of Cement Mortar
}

\author{
Sura A. Majeed \\ Assistant Lecturer \\ Civil Engineering Department- Mosul University
}

\begin{abstract}
The present paper deals with studying the effect of sand/cement (s/c) ratio and water/cement $(\mathrm{w} / \mathrm{c})$ ratio on the mechanical properties of cement mortar and to predict a relationship between modulus of rupture and compressive strength for the cement mortar. In the present work seventy two sample of cubes and prisms were tested for compressive strength and modulus of rupture. All the tests were carried out in accordance to the ASTM specification C109 using twelve different mix proportions of cement/sand ratio and water/cement ratio. From the test results and based on regression analysis a best power relation between modulus of rupture and compressive strength are proposed.
\end{abstract}

Keywords: compressive strength, modulus of rupture, mortar, sand.

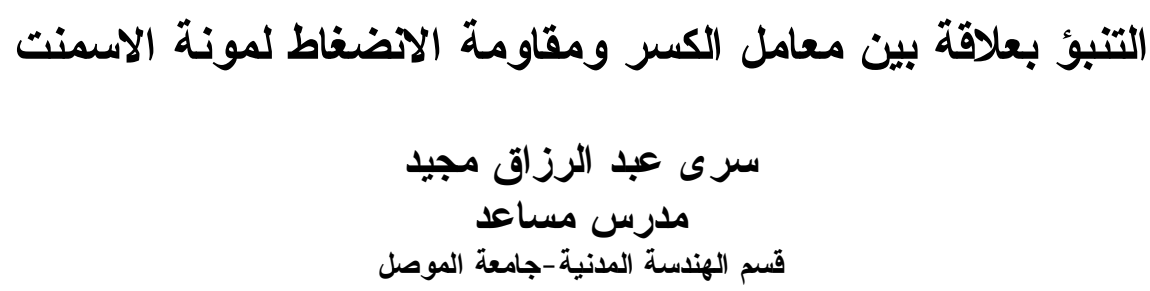

\footnotetext{
الخلاصة

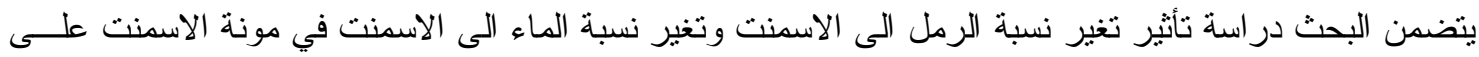

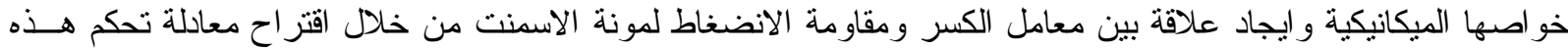

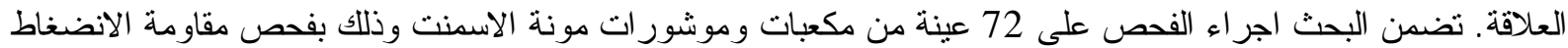

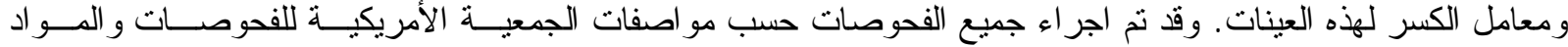
ASTM الفحص من هذه الدر اسة لاشتقاق معادلة تجريبية للعلاقة بين معامل الكسر ومقاومة الانضغاط لمونة الإنة الاسمنت.
} 


\begin{tabular}{lllll} 
Al-Rafidain Engineering & Vol.17 & No.5 & October & 2009 \\
\hline
\end{tabular}

\section{Introduction}

Cement mortar is widely used for joining the building materials (bricks, stone and concrete blocks), plastering and tile placing. It is also used in ferrocement which is widely used for restoration of structures, lining of tunnels...etc [1, 2]. In such type of ferrocement structures, like slabs, domes...etc, it is necessary to know the modulus of rupture of the mortar and this requires studying the effect of sand/cement ratio and w/c ratio on its compressive strength, modulus of rupture and the relationship between them.

The relationship between modulus of rupture and compressive strength is not well defined as it is the case in concrete materials, and this is due to the limited number of the experimental data of mortar. Previous studies [3] reported a considerable variation in the properties of mortar even for the same compositions and category when different water/cement (w/c) ratios were used.On the other hand, in an early site survey [4] carried out in Riyadh area (in Saudi Arabia) to collect data about the manufacturing process and the properties of mortar as well as bricks/blocks and their constituents produced in the area, it was observed that some of the mortar and bricks/blocks manufacturers prefer to use white sand rather than red sand in producing the units. Amjad et. al. [5] studied the effect of type of sand on the mechanical properties of the mortar. The tests included compressive and flexural strengths, modulus of elasticity, drying shrinkage, specific gravity and absorption. The main variables in the investigation were the type of sand and mix proportions. Based on the test results, the following conclusions are drawn:

1- Replacing red sand with white sand increases the compressive strength, flexural strength, and modulus of elasticity, and decreases the drying shrinkage of the mortar.

2- The type of sand has an insignificant effect on the density and water absorption of the mortar and concrete bricks.

3- Addition of lime to mortar mix adversely affects its mechanical and physical properties. Also, replacing red sand by white sand in mortar mixes containing lime is less effective in mitigating the drying shrinkage.

The present paper presents the results of tests carried out to investigate the influence of variation of sand/cement ratio and water/cement ratio on the compressive strength and modulus of rupture of the mortar and to suggest a relation between the modulus of rupture and compressive strength of the cement mortar.

\section{Test program}

To study the effects of varying sand/cement ratio and water/cement ratio on the compressive and flexural strength of cement mortar, it was proposed to use twelve mix proportions having different sand/cement ratios and water/cement ratios as given in (Table-1).

Table-1 Details of mix proportions.

\begin{tabular}{|c|c|c|c|c|}
\hline w/c ratio & \multicolumn{4}{|c|}{ s/c ratio } \\
\hline 0.35 & $1: 1.5$ & $1: 2$ & $1: 2.5$ & $1: 3$ \\
\hline 0.45 & $1: 1.5$ & $1: 2$ & $1: 2.5$ & $1: 3$ \\
\hline 0.55 & $1: 1.5$ & $1: 2$ & $1: 2.5$ & $1: 3$ \\
\hline
\end{tabular}

For each mix proportions 3 cube samples of size $(50 \times 50 \times 50 \mathrm{~mm})$ are molded for compressive strength and 3 prisms of size $(25 \times 25 \times 300 \mathrm{~mm})$ are molded for flexural strength. In all the mixes the same procedure was followed for mixing, curing and testing the samples. Graded river sand near Mosul city was used for making test samples. The results of sieve analysis of representative 
sample of sand are plotted in Fig. (1) which conforms with the ASTM (C-33) [6]. The fineness modulus of the sand is equal to 2.86. For all mixes of the mortars, Portland cement (Type I) produced locally that comply with the Iraqi Specification (IQS. No.5,1985) [7] was used. Its main chemical and physical properties are given in (Table-2).

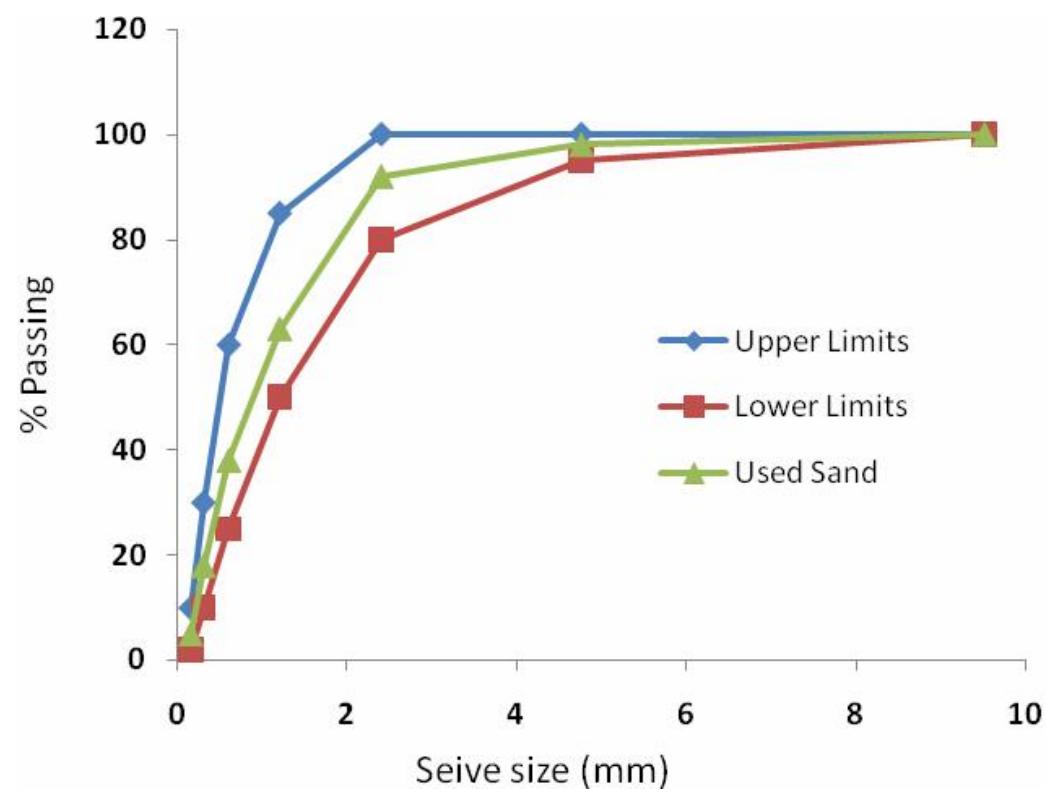

Fig. 1: Sieve analysis of representative sample of sand.

Table-2 chemical and physical properties of the used cement.

\section{chemical properties}

\begin{tabular}{|c|c|c|c|c|c|c|c|c|c|}
\hline IR & $\mathrm{SIO}_{2}$ & $\mathrm{Fe}_{2} \mathrm{O} 3$ & $\mathrm{Al}_{2} \mathrm{O}_{3}$ & $\mathrm{CaO}$ & $\mathrm{MgO}$ & $\mathrm{SO}_{3}$ & LOI & LSF & Total \\
\hline 0.21 & 21.0 & 5.2 & 4.3 & 61.3 & 3 & 2.4 & 2.2 & 0.88 & 99.61 \\
\hline
\end{tabular}

\begin{tabular}{|c|c|c|c|c|c|c|}
\hline \multicolumn{7}{|c|}{ physical properties } \\
\hline $\begin{array}{c}\text { Fineness } \\
\text { Modulus\% }\end{array}$ & $\begin{array}{c}\text { Extension } \\
(\mathrm{mm})\end{array}$ & $\begin{array}{c}\text { Modulus } \\
\text { of } \\
\text { Fluidity }\end{array}$ & $\begin{array}{c}\text { Initial } \\
\text { Setting } \\
\text { Time } \\
(\mathrm{min})\end{array}$ & $\begin{array}{c}\text { Final } \\
\text { Setting } \\
\text { Time } \\
(\mathrm{min})\end{array}$ & $\begin{array}{c}\text { Comp. } \\
\text { Strength } \\
\text { at 3 days } \\
(\mathrm{Mpa})\end{array}$ & $\begin{array}{c}\text { Comp. } \\
\text { Strength } \\
\text { at 7 days } \\
(\mathrm{Mpa})\end{array}$ \\
\hline 1 & 2 & 0.29 & 135 & 300 & 25.2 & 33.8 \\
\hline
\end{tabular}

The chemical and physical properties that are given in (Table-2), show that it is comply with the classification of Ordinary Portland Cement (Type I) [7].

Tap drinking water was used for mixing and curing, the temperature of the water for mixing and curing is in the range of $\left(25 \pm 5^{\circ} \mathrm{C}\right)$. Cement, sand and water were measured by weight in accordance with the respective proportions. The molding are took place under laboratory conditions at a temperature of $\left(25 \pm 5^{\circ} \mathrm{C}\right)$ and a relative humidity ranged between $(50-60 \%)$. 


\section{$\begin{array}{llll}\text { Al-Rafidain Engineering } & \text { Vol.17 } & \text { No.5 } & \text { October } 2009\end{array}$}

Samples were kept in the mold for 24 hours after casting and the samples are removed from the molds and kept in the curing water tell the date of testing at the age of 28 days. The details of mortar samples for different tests are given below:

1- Thirty six cubes $(50 \times 50 \times 50 \mathrm{~mm})$ of different mix proportions were molded and tested to determine the compressive strength after 28 days of water curing in the laboratory. The test was carried out as per ASTM C109-92 specifications [8] using compression test machine (ELE) with loading rate within the range of $900-1800 \mathrm{~N} / \mathrm{s}$. All the samples are tested as soon as they are removed from the curing tank.

2- Thirty six Prisms $(25 \times 25 \times 300 \mathrm{~mm})$ of different mix proportions were molded and tested to determine the modulus of rupture after 28 days of water curing in the laboratory. All the samples are tested under third point load test over a span of $200 \mathrm{~mm}$ to obtain a zone of pure flexure. All the samples are tested as soon as they are removed from the curing tank. The test was carried out as per ASTM C348-93 specifications [9].

To prepare a particular mix the required amount of cement is weighted and the corresponding quantity of saturated surface dry sand used in each mix according to the proportion of sand/cement ratio is prepared and the quantity of water for mixing also weighted according to the water/cement ratio stated in (Table-1). The procedure of casting and testing is carried out as per the ASTM C109-92 specifications [8] and ASTM C348-93 specifications [9]. Fig.(2) shows sample of tested cubes and prisms specimens.

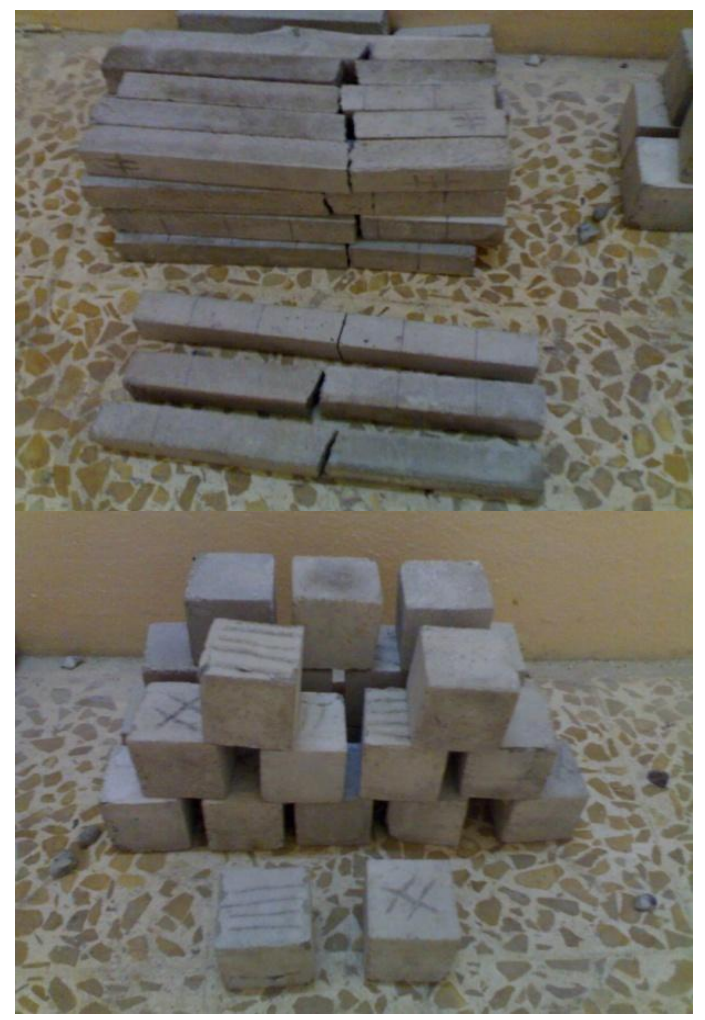

Fig. 2: Sample of tested specimens. 


\section{Results and discussion}

The test results presented in terms of compressive strength and modulus of rupture are listed in (Table-3). Each value is the average of three samples. The statistical analysis of the experimental results for $\boldsymbol{f}_{\boldsymbol{r}_{\boldsymbol{m}}}$ and $\boldsymbol{f}_{\boldsymbol{c}_{\boldsymbol{m}}}^{\prime}$ using SPSS V11.5 program are listed in (Table-4).

The variation of compressive strength $\boldsymbol{f}_{\boldsymbol{c}_{\boldsymbol{m}}}^{\prime}$ and modulus of rupture $\boldsymbol{f}_{\boldsymbol{r}_{\boldsymbol{m}}}$ with the sand/cement (s/c) ratio are shown in Fig.(3) and Fig.(4) respectively for the three different w/c ratios $(0.35,0.45,0.55)$. As can be seen from these two figures that the strength of the sample having s/c ratio equal to 1.5 and 2 with w/c ratio equal to 0.35 is higher than that with w/c ratio equal to 0.55 but less than that with w/c ratio equal to 0.45 . When the s/c ratio increases to 2.5 and 3 with w/c ratio equal to 0.35 the strength of these mixes are less than other mixes. This can be attributed to the very poor workability of the fresh mortar having w/c ratio equal to 0.35 with $\mathrm{s} / \mathrm{c}$ ratio equal to 2.5 and 3 were the fresh mortar are crumply and the solid mortar are very porous and weaker than that of the other mixes.

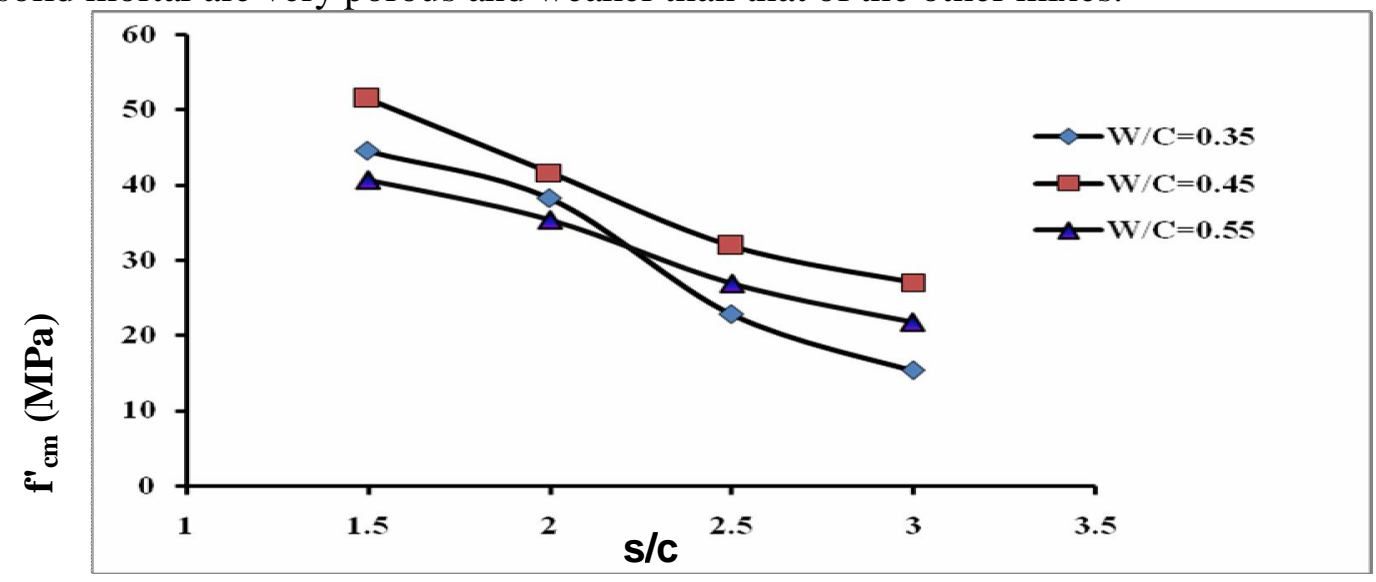

Fig. 3: Variation of compressive strength $f_{c_{m}}^{\prime}$ with the sand/cement (s/c) ratio for different $w / c$ ratio.

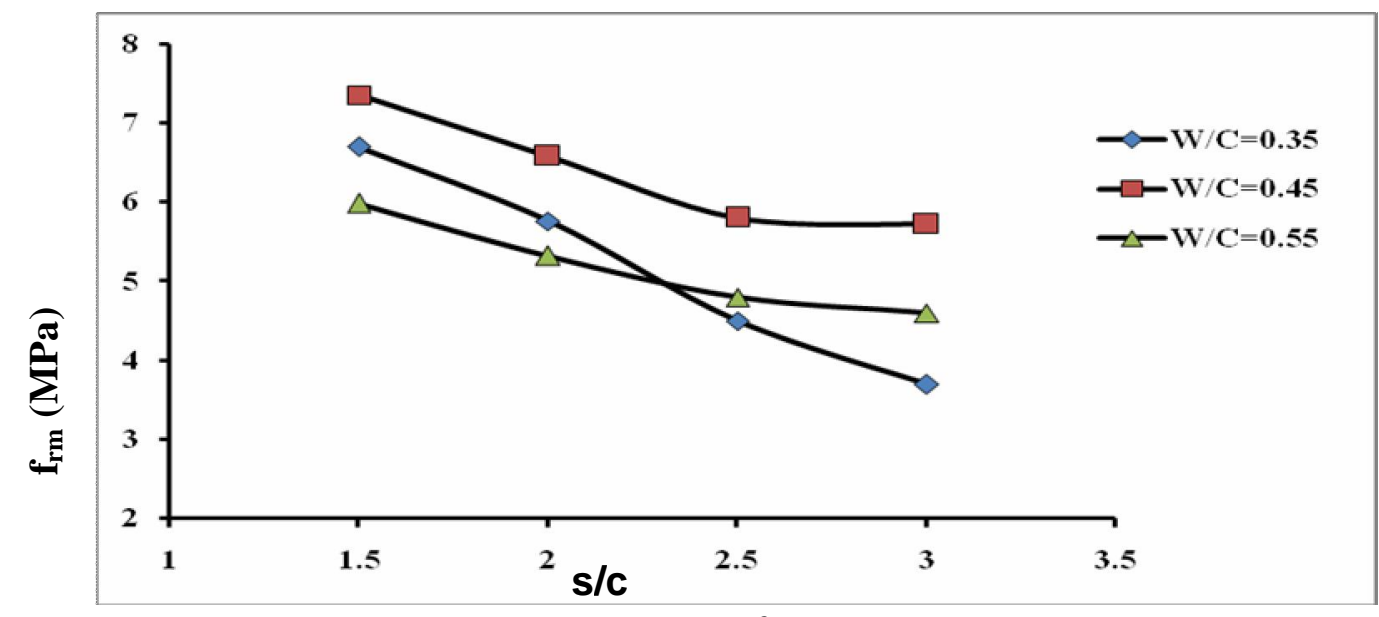

Fig. 4: Variation of modulus of rupture $f_{r_{m}}$ with the sand/cement (s/c) ratio for different $w / c$ ratio. 
The variation of compressive strength $f_{\boldsymbol{c}_{\boldsymbol{m}}}^{\prime}$ and modulus of rupture $\boldsymbol{f}_{\boldsymbol{r}_{\boldsymbol{m}}}$ with the water/cement (w/c) ratio is shown in Fig.(5) and Fig.(6) respectively for the four different sand/cement (s/c) ratio. These two figures show that for all the $\mathrm{s} / \mathrm{c}$ ratios the strength of the mixes with w/c ratio equal to 0.45 is higher than that with w/c ratio equal to 0.35 or 0.55 .

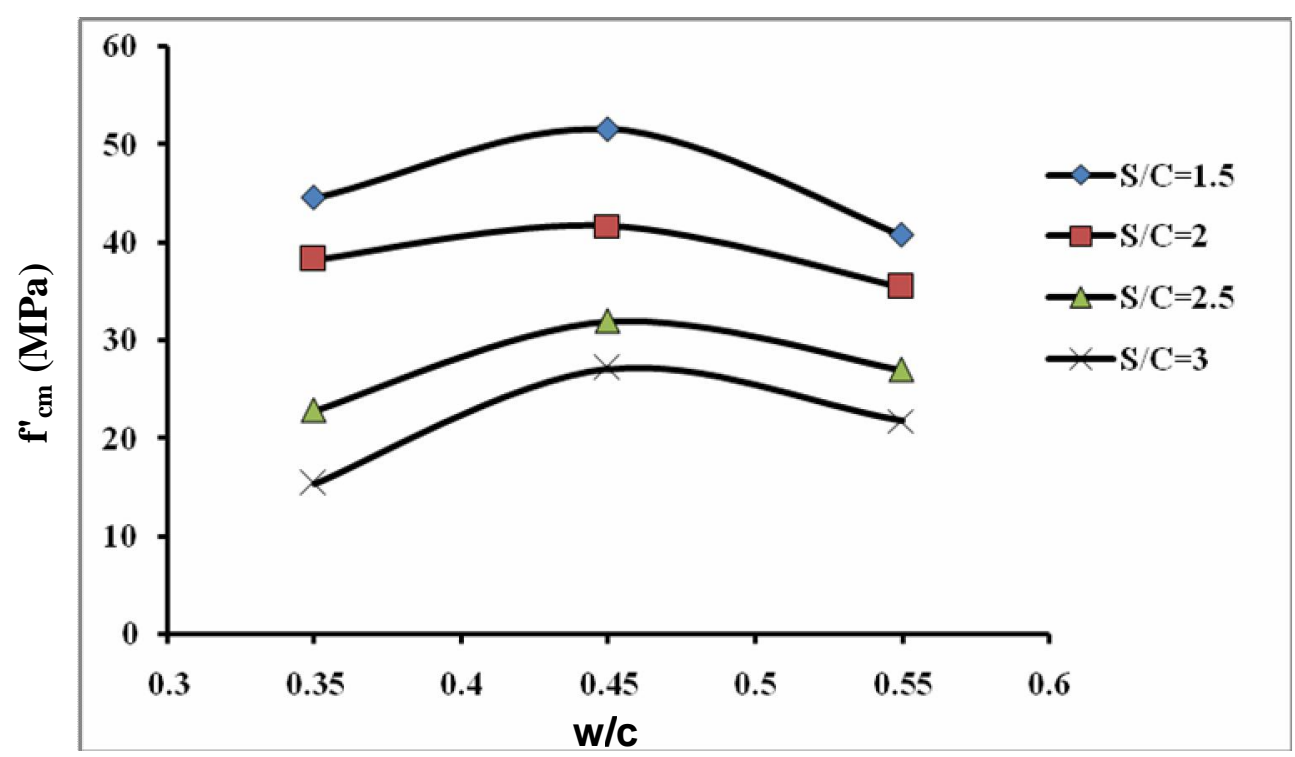

Fig. 5: Variation of compressive strength $f_{c_{m}}^{\prime}$ with the water/cement $(w / c)$ ratio for different $s / c$ ratio.

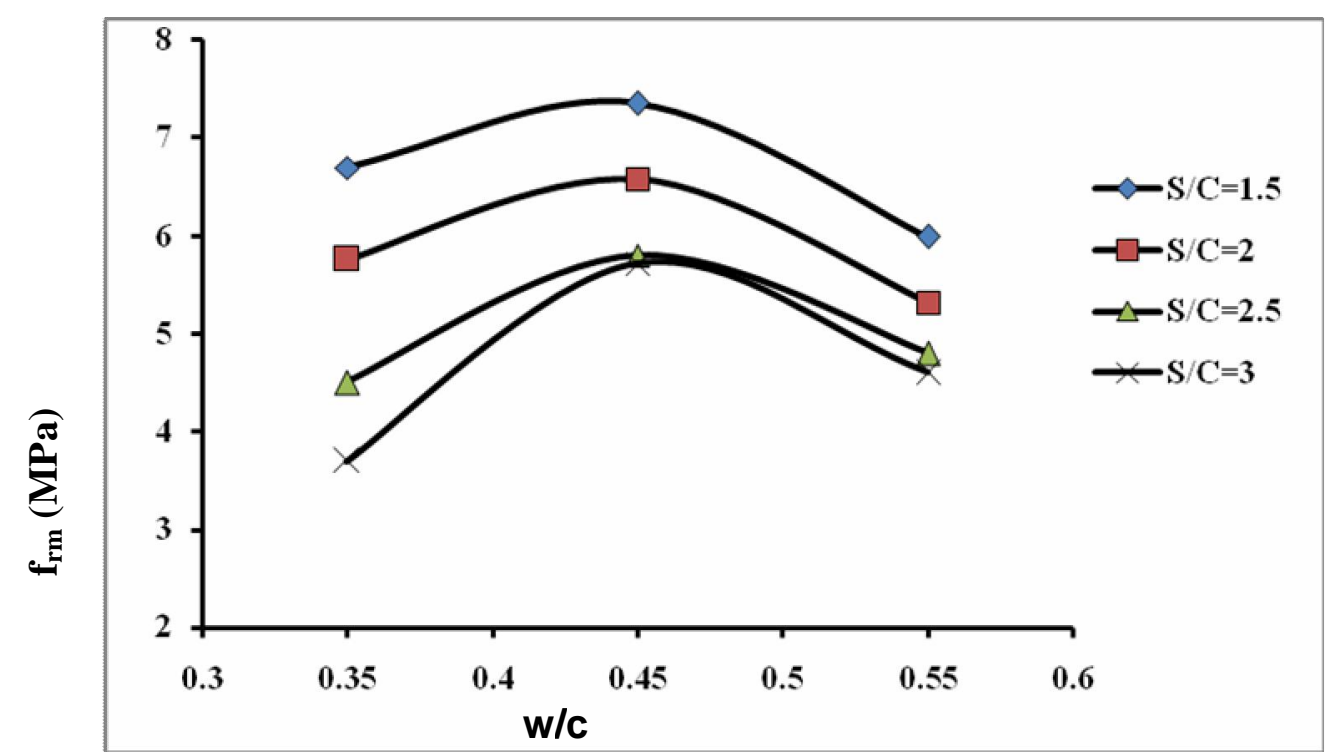

Fig. 6: Variation of modulus of rupture $f_{r_{m}}$ with the water/cement (w/c) ratio for different $\mathrm{s} / \mathrm{c}$ ratio. 
As expected the strength of mortar in terms of compressive strength and modulus of rupture is reduced with the increase in the s/c ratio. The reduction ranged between (13-66)\% for the compressive strength and (10-45)\% for the modulus of rupture if s/c ratio equal to (1.5) is taken as a reference.

The relation between the modulus of rupture $\boldsymbol{f}_{\boldsymbol{r}_{\boldsymbol{m}}}$ and compressive strength $\boldsymbol{f}_{\boldsymbol{c}_{\boldsymbol{m}}}^{\prime}$ of the mortar determined in this study are shown in Fig.(7) and the power relation that correlates these two variables, using SPSS V 11.5 program, can be written as:

$f_{r_{m}}=0.88\left(f_{c_{m}^{\prime}}^{\prime}\right)^{0.53}$

With $\mathrm{R}^{2}$ value equal to 0.9025

Where

$\boldsymbol{f}_{\boldsymbol{r}_{\boldsymbol{m}}}$ :Modulus of rupture of mortar, MPa.

$f_{c_{\boldsymbol{m}}}^{\prime}$ : Compressive strength of mortar, MPa.

The predicted values of $\boldsymbol{f}_{\boldsymbol{r}_{\boldsymbol{m}}}$ using Eq.(1) are given in (Table-3) which are also plotted in Fig.(7). The standard error of the estimate for the values determined from Eq.(1) corresponding to the experimental $\boldsymbol{f}_{\boldsymbol{r}_{\boldsymbol{m}}}$ is equal to (0.3421).

Eq.(1) is modified such that the power is taken equal to 0.5 and by using least square method to minimize the error with respect to the constant multiplier, the modified equations can be written as:

$f_{r_{m}}=0.97 \sqrt{f_{c_{m}}^{\prime}}$

With $\mathrm{R}^{2}$ value equal to 0.8952 .

The predicted values of $\boldsymbol{f}_{\boldsymbol{r}_{\boldsymbol{m}}}$ using Eq.(2) are also given in (Table-3) and the same are plotted in Fig.(7). The standard error of the estimate for Eq.(2) is equal to 0.3546. As can be seen the standard error of the estimate for the two equations are almost same with $(3.6 \%)$ difference. So Eq.(2) may be recommended for this relation.

To check the accuracy of these two relations, the determined values of modulus of rupture from Eq. (1) are assigned a notation $f_{\boldsymbol{r}_{\boldsymbol{m} \mathbf{0 . 8 8}}}$ and a linear regression is carried out between the experimental $\boldsymbol{f}_{\boldsymbol{r}_{\boldsymbol{m}}}$ and $\boldsymbol{f}_{\boldsymbol{r}_{\boldsymbol{m} \mathbf{0 . 8 8}}}$ and the following relation is determined:

$$
f_{r_{m}}=-0.022+1.003 f_{r_{m} \mathbf{0 . 8 8}}
$$

which gives a constant almost equal to zero and a slope equal to unity which indicate a good correlation between the experimental and the predicted values using Eq. (1). In the same manner if the predicted values of modulus of rupture from Eq. (2) are assigned a notation 


\section{$\begin{array}{llll}\text { Al-Rafidain Engineering } & \text { Vol.17 } & \text { No.5 } & \text { October } 2009\end{array}$}

$f_{\boldsymbol{r}_{\boldsymbol{m} \mathbf{0 . 9 7}}}$ and a linear regression is carried out between the experimental $\boldsymbol{f}_{\boldsymbol{r}_{\boldsymbol{m}}}$ and $\boldsymbol{f}_{\boldsymbol{r}_{\boldsymbol{m} \mathbf{0 . 9 7}}}$, the following relation is determined:

$$
f_{\boldsymbol{r}_{\boldsymbol{m}}}=-0.341+1.07 \boldsymbol{f}_{\boldsymbol{r}_{\boldsymbol{m} \mathbf{0 . 9 7}}}
$$

Which also shows that the slope of the line is almost equal to unity but the constant is greater than that of Eq.(3), nevertheless; the relationship may be considered as acceptable one and Fig. (7) depict this fact.

Table-3 The test results of compressive strength and modulus of rupture.

\begin{tabular}{|c|c|c|c|c|c|}
\hline $\begin{array}{c}\mathrm{s} / \mathrm{c} \\
\text { ratio }\end{array}$ & $\begin{array}{c}\text { w/c } \\
\text { ratio }\end{array}$ & $\begin{array}{c}f_{c_{m}}^{\prime} \\
(\mathbf{M P a})\end{array}$ & $\begin{array}{c}f_{r_{m}} \\
(\mathbf{M P a})\end{array}$ & $\begin{array}{c}f_{r_{m}} \\
(\mathbf{M P a}) \\
\text { Eq.(1) }\end{array}$ & $\begin{array}{c}f_{r_{m}} \\
\text { (MPa) } \\
\text { Eq.(2) }\end{array}$ \\
\hline \multirow{3}{*}{$1: 1.5$} & 0.35 & 44.6 & 6.7 & 6.54 & 6.48 \\
\hline & 0.45 & 51.61 & 7.36 & 7.09 & 6.97 \\
\hline & 0.55 & 40.79 & 5.99 & 6.23 & 6.2 \\
\hline \multirow{3}{*}{$1: 2$} & 0.35 & 38.33 & 5.76 & 6.02 & 6.01 \\
\hline & 0.45 & 41.71 & 6.58 & 6.3 & 6.26 \\
\hline & 0.55 & 35.5 & 5.32 & 5.77 & 5.78 \\
\hline \multirow{3}{*}{$1: 2.5$} & 0.35 & 22.9 & 4.5 & 4.63 & 4.64 \\
\hline & 0.45 & 32 & 5.8 & 5.45 & 5.49 \\
\hline & 0.55 & 27 & 4.8 & 4.96 & 5.04 \\
\hline \multirow{3}{*}{$1: 3$} & 0.35 & 15.4 & 3.7 & 3.64 & 3.81 \\
\hline & 0.45 & 27.15 & 5.72 & 4.98 & 5.05 \\
\hline & 0.55 & 21.84 & 4.6 & 4.42 & 4.53 \\
\hline
\end{tabular}

Table- 4 Statistical analysis of the experimental data.

\begin{tabular}{|c|c|c|}
\hline & $\boldsymbol{f}_{\boldsymbol{r} \boldsymbol{m}}$ & $\boldsymbol{f}_{\boldsymbol{c}_{\boldsymbol{m}}}$ \\
\hline $\mathbf{N}$ Valid & 12 & 12 \\
\hline Missing & 0 & 0 \\
\hline Mean & 5.5684417 & 33.2377767 \\
\hline Std. Error of Mean & .30158799 & 3.08839792 \\
\hline Std. Deviation & 1.04473144 & 10.69852423 \\
\hline Variance & 1.09146378 & 114.45842080 \\
\hline Minimum & 3.70000 & 15.40333 \\
\hline Maximum & 7.35500 & 51.61333 \\
\hline
\end{tabular}




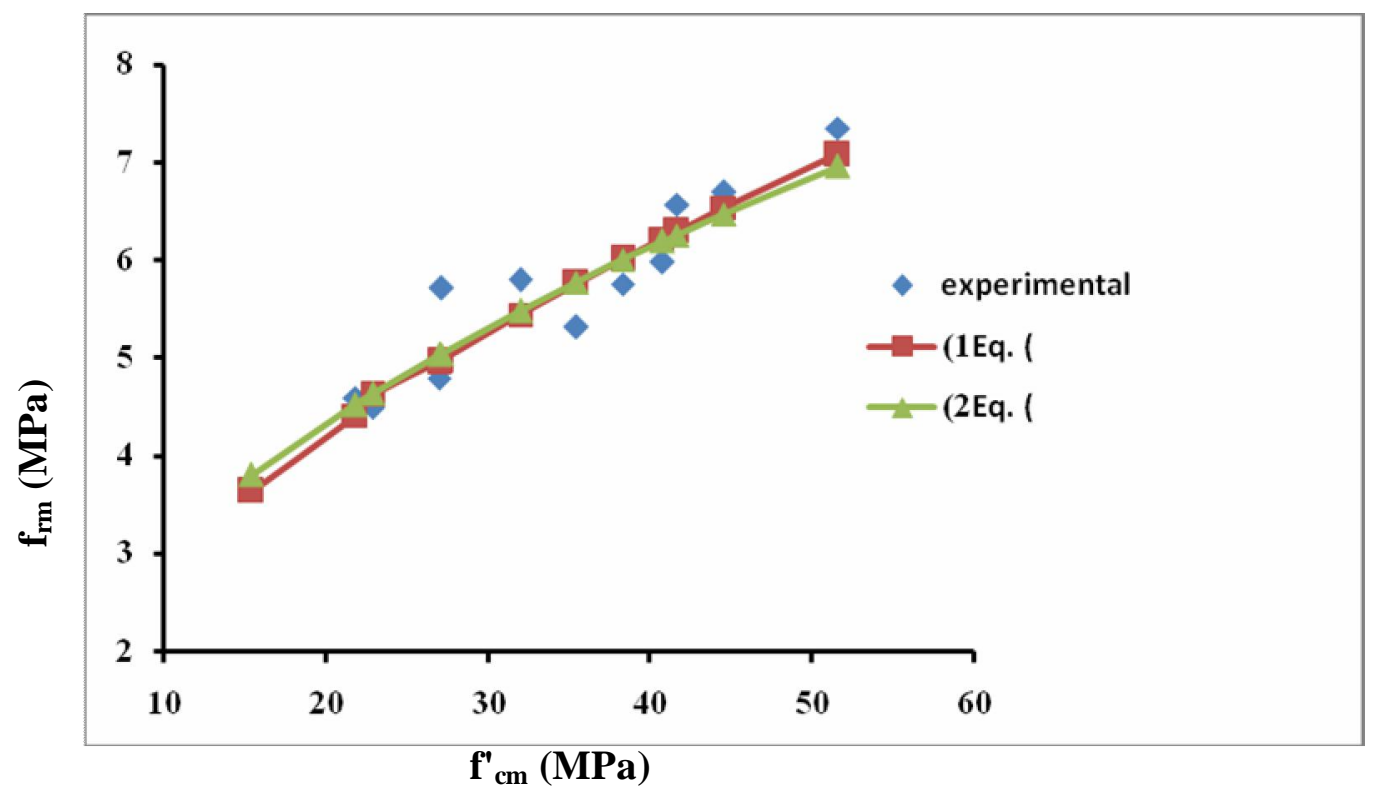

Fig.7: Variation of modulus of rupture $f_{r_{m}}$ with compressive strength $f_{c_{m}}^{\prime}$.

\section{Conclusions and Recommendations}

Based on the limited experimental results obtained from the laboratory tests of flexural and compressive strength of different mortar mixes, the following conclusions may be stated:

1- An increase in $(\mathrm{s} / \mathrm{c})$ ratio leads to a decrease in the compressive strength and modulus of rupture of the mortar in the range of (13-66)\% for compressive strength and (10-45)\% for modulus of rupture if $\mathrm{s} / \mathrm{c}$ ratio equal to 1.5 is taken as a reference.

2- The change of $w / c$ ratio significantly affects the mortar cement strength. The determined higher mortar strength for all the $\mathrm{s} / \mathrm{c}$ ratios is that corresponding to $\mathrm{w} / \mathrm{c}$ ratio equal to 0.45 .

3- Based on the regression analysis, a power relationship that relate modulus of rupture to the compressive strength of the mortar are derived and simplified version is proposed which was found to give a good correlation with the experimental results.

The present work can be extended by studying the effects of adding some admixture that improve the workability, initial setting and strength on the flexural and compressive strength of the mortar and the relationships between them.

\section{References}

1- A. Th. Vermmeltfoort, "Mechanical Properties under Compression of Masonry and Its Components", Proceeding of the $6^{\text {th }}$ Canadian Masonry symposium, Saskatoon, Canada, 1992, pp. 657-662.

2- A. M. Neville, Properties of concrete, $3^{\text {rd }}$ edn. London: Longman Scientific \& technical, 1981, 779pp.

3- M. A. Amjad, O. Al-Harbi, A. Al-Abdulaaly, A. Al-Sary, S. Al- Sayed and M. Idrees, "Properties of White Sand in Riyadh Area and Its Utilization", Final Report, AR-13-5. Riyadh, Saudi Arabia: KACST, March 1997, pp. 32. 


\section{$\begin{array}{llll}\text { Al-Rafidain Engineering } & \text { Vol.17 } & \text { No.5 } & \text { October } 2009\end{array}$}

4- M. A. Amjad, S. Alsayed, O. Al-Harbi, and G. Khater, "Influence of Silica Sand on the Properties of Concrete Blocks and Mortar", Proceedings of the First Regioal Conference and Exhibition, American Society of Civil Engineers-Saudi Arabia Section (ASCE-SAS): Advanced Technology in Civil Engineering, Manama, Bahrain, September 18-20, 1994, pp. 505-610.

5- M. A. Amjad and S. H. Alsayed, "Properties of Mortar, Bricks, and Masonry Incorporating Red and White Sands", The Arabian Journal for Science and Engineering, Volume 24, Number 2B, October 1999, pp.169-184.

6- ASTM (C-33), "Specification for Concrete Aggregate", 1978.

$$
\text { 7- المو اصفة القياسية العر اقية رقم (5) لسنة } 1985 \text { (الاسمنت البورتلاندي). }
$$

8- "Standard Test Method for Compressive Strength of Hydraulic Cement Mortar", ASTM C109-92. Philadelphia: ASTM, 1992, Vol. 4.01, pp.64-68.

9- "Standard Test Method for flexural Strength of Hydraulic Cement Mortar", ASTM C34893. Philadelphia: ASTM, 1993, Vol. 4.01, pp.208-213. 